\title{
DEVELOPMENT AND EVALUATION OF A PORTABLE FORCED AIR PRE-COOLING UNIT \\ Abd-Alla, H.E. ${ }^{1}$; M.M. Elkholy ${ }^{2}$ and M.S. Radwan ${ }^{3}$ \\ 1 Agric. Engin. Dept., Fac. of Agric., Mansoura Univ. \\ 2 Agric. Crop Agric. Eng. Res. Institute. \\ ${ }^{3}$ Ministry of Agriculture, Egypt.
}

\begin{abstract}
A study was carried out at the experimental station of Rice Mechanization Center (R.M.C.), Meet El-Deyba, Kafr El-Sheikh Governorate, during 2007 and 2008 seasons. The experimental work included design, developing and testing a portable pre-cooling unit for fruits and vegetables. Quality changes of the pre-cooled products in comparison with the none cooled product were also determined during storage process under two different storage conditions (coled and room storage methods). The laboratory experiments were conducted for pre-cooling tomato fruits at three different levels of air temperature $\left(4,7\right.$ and $\left.10^{\circ} \mathrm{C}\right)$, three levels of air velocity $(3.7,4.8$ and $5.4 \mathrm{~m} / \mathrm{s}$ ), three levels of packages vents percentage (4, 6 and $8 \%$ ) and two volumes of fruits (medium and large). The results showed rapid drop in product temperature at the beginning of cooling process and the cooling rate starts to decline as the product temperature approaches the final temperature. The values of cooling coefficient $(\mathrm{C})$ increased with the increase of air velocity $(\mathrm{V})$, increase of packages vents percentage, decrease of fruit volume and decrease of medium cooling air temperature. While, the half and seven-eighth cooling times decreased with the increase of air velocity and increase of packages vents percentage and they were increased with the increase of cooling temperature and increase of product volume. The storage experiments showed that, the pre-cooled tomato fruits recorded lower water loss, lower percentage of defect, and higher fruit firmness in comparison with the none cooled samples.
\end{abstract}

\section{INTRODUCTION}

Tomato is an important vegetable crop that is available throughout the year in most of the tropical countries with seasonal peaks during JuneOctober. During the peak season they are available in plenty resulting in high heat which affecting in distress sales; as prices come down. In Egypt the planted area of tomato crops is 537,208 Fadden, which product about, 8639024 tones (M. O. A., 2008).

One of the most important factors affecting the post harvest life and quality of horticultural crops is temperature. Quality loss after harvest occurs as a result of physiological and biological processes, the rates of which are influenced primarily by product temperature. As the maintenance of market quality is of vital importance to the success of the horticultural industry, it is necessary not only to cool the product but to cool it as quickly as possible after harvest Kalbasi (2004).

The normal harvest temperature for the fruits and vegetables is quite high, approximately 25 to $32^{\circ} \mathrm{C}$. At that condition the product physiological and chemical process is high, and consequently shelf life is reduced. 
Abd-Alla, H.E. et al.

Small farmers has long realized this problem thereby it has been a practice to harvest early in the morning in order to take advantage of the lower temperatures generally prevailing at that times. However, early morning harvesting may not be feasible for large growers and morning temperatures may still be relatively high for optimum harvesting $\left(25\right.$ to $\left.27^{\circ} \mathrm{C}\right)$, so pre-cooling fruits and vegetables is the important process to maintain product quality Abd-Alla (1997).

Pre-cooling is referred to as one of the more important component in the total operation of establishing and maintaining the proper environment which delays senescence and maintains the best possible shelf life quality. Pre-cooling is the first step in good temperature management. The field heat of freshly harvested crop is usually high, and should be removed as quickly as possible before shipping, processing, or storage. Pre-cooling by removing field heat from freshly harvested fruits reduces microbial activity and respiration rates. Furthermore, senescence of fruit as well as ethylene production is also eliminated. This condition decreases the ripening rate, diminishes water loss and decay, and thus, helps preserving quality and prolongs shelf life of the fruits (Ferreira et al. 1994 and Reina et al. 1995).

Farragher et al. (1984) reported that the rate of deterioration after harvest is closely related to the respiration rate of the harvested product, therefore the reduction of respiration rate is essential to preserving market quality. Since the rate of respiration is influenced by temperature.

Shewfelt (1986) believes that for many product, pre-cooling may be the single most important step in extending their shelf life and maintaining the high quality required at customer level.

There are varieties of pre-cooling techniques available for use in the horticultural industry. The principal methods of pre-cooling highly perishable produce include room cooling, hydro-cooling, forced air cooling, package icing, vacuum cooling and cryogenic cooling, with many variations and alterations within these techniques, Brosnan and Da- Wen (2001).

Kader (1992) found that, good temperature management is the most important factor in delaying product deterioration; prompt cooling and maintenance of proper temperature are both essential. For many products, maintaining as low temperature as possible without danger of freezing is found to be essential. He also found that each $10^{\circ} \mathrm{C}$ temperature reduction reduces respiratory activity by a factor of 2 to 4 . The respiratory rate of a product at $5^{\circ} \mathrm{C}$ would be only one-forth to one-sixteenth of what it would be at $25^{\circ} \mathrm{C}$; therefore good cooling and temperature practices are critical to slowing physiological deterioration.

Schofer et al. (1992) described the design and construction of a portable farm-built pre-cooler for fruits and vegetables, known as the portable cooler. It is especially useful for high value crops. The purpose of the portable cooler is to remove detrimental field heat soon after harvesting, thus improving product quality. They reported that, cooling of fruits to maintain their fresh condition between harvest and consumption greatly influences their values. As soon as mature fruits are harvested, they begin a slow process of drying and the period of their good appearance and value is 
influenced by how fast they use their stored energy in continuing life. Proper temperature and humidity control can extend the period of fresh appearance.

The present study aims to developing and testing a portable precooling unit. The quality changes and the safe storage period of the percooled products were also determined for tomato fruits.

\section{MATERIALS AND METHODS}

This study was carried out at the experimental Station of Rice Mechanization Center (R.M.C.), Meet El-Deyba, Kafr El-Sheikh Governorate during 2007 and 2008 seasons. The experimental work included design developing and testing a portable pre-cooling unit for fruits and vegetables. Quality changes of the pre-cooled products in comparison with the none cooled product were also determined for the tested tomato fruits.

\section{Analysis Of The Cooling Process:}

Considering homogeneous thermal and physical properties of the product and the cooling medium when operating under the unsteady state conditions (Dincer et al., 1992 and Shokr et al., 1994). The change in temperature of the object can be related to the heat transferred by convection from the surface of the subject to the surrounding air.

$$
-M c d T=h A\left(T-T_{a}\right) d t
$$

Where:

$$
\begin{aligned}
& M=\text { mass of object, } \mathrm{kg} \\
& \mathrm{C}=\text { specific heat } \mathrm{J} / \mathrm{kg} .{ }^{\circ} \mathrm{k} \\
& \mathrm{A}=\text { surface area of the object, } \mathrm{m}^{2} \\
& \mathrm{~h}=\text { convective coefficient, } \mathrm{W} / \mathrm{m}^{2} .{ }^{\circ} \mathrm{K} \\
& T=\text { temperature of the object, }{ }^{\circ} \mathrm{C} \\
& T_{a}=\text { temperature of the surrounding, }{ }^{\circ} \mathrm{C} \\
& \mathrm{t}=\text { time, sec. }
\end{aligned}
$$

If the surrounding temperature is constant, equation (1) has the following solution

$$
\operatorname{Ln}\left(\frac{T-T_{a}}{T_{i}-T_{a}}\right)=-\frac{h A}{M c} t
$$

The term $\frac{h A}{M c}$ is considered constant (C) known as a cooling coefficient

$$
\frac{T-T_{a}}{T_{i}-T_{a}} \text { is considered }(\theta) \text { known as temperature ratio, }
$$

dimensionless temperature ratio is defined as the unaccomplished temperature change at any time in relation to the total temperature possible change for a particular cooling condition.

$$
\operatorname{Ln}(\theta)=-C t
$$


Abd-Alla, H.E. et al.

The dimensionless temperature change with time is generally expressed in the form of an exponential equation, including the cooling parameters in terms of a cooling coefficient as follows:

$$
\theta=J \exp (-C t)
$$

Where:

$\mathrm{C}=$ cooling coefficient (the slope of the line resulting from a plot of the natural log of the temperature ratio versus time, inverse time)

$\mathrm{J}=$ Lag factor (the intercept of the straight-line asymptote at time o)

$$
\begin{aligned}
& \operatorname{Ln} \theta=\operatorname{LnJ}-C t \\
& \operatorname{Ln} \frac{J}{\theta}=C t
\end{aligned}
$$

The cooling coefficient denotes the change in product temperature difference between the product and its surroundings. By substituting $\theta=1 / 2$ into equ.(6), the half cooling time $\mathrm{H}$, is obtained by the following equation:

$$
\operatorname{Ln} \frac{J}{1 / 2}=C t_{1 / 2}
$$

Then

$$
H=t_{1 / 2}=\frac{\ln 2 J}{C}
$$

By substituting $\theta=1 / 8$ into equ. (6), the seven-eighth cooling time $S$ is calculated as follows:

$$
S=\frac{\ln 8 J}{C}
$$

\section{Components Of The Pre-Cooling Unit:}

Figure (1) illustrates elevation and plan of the portable pre-cooling unit used for the experimental work. The main frame of the developed unit was constructed of $(4 \times 4 \mathrm{~cm})$ iron angles with dimensions of $215.6 \mathrm{~cm}$ long, $62 \mathrm{~cm}$ wide and $120 \mathrm{~cm}$ high. The main frame was fixed on four wheels of $25 \mathrm{~cm}$ diameter. The cooling chamber, refrigerating system and humidifying system were assembled on the main frame. The cooling chamber constructed of double galvanized steel sheets $(1 \mathrm{~mm}$ thick) filled with $7.7 \mathrm{~cm}$ thick polyurethane foam at an injected density of $38-40 \mathrm{~kg} / \mathrm{m}^{3}$. Two doors were fixed on the front side of the chamber frame. The first door was used for charging and discharging the product, while the second door was used for the accommodation part of the refrigeration and the control units. 


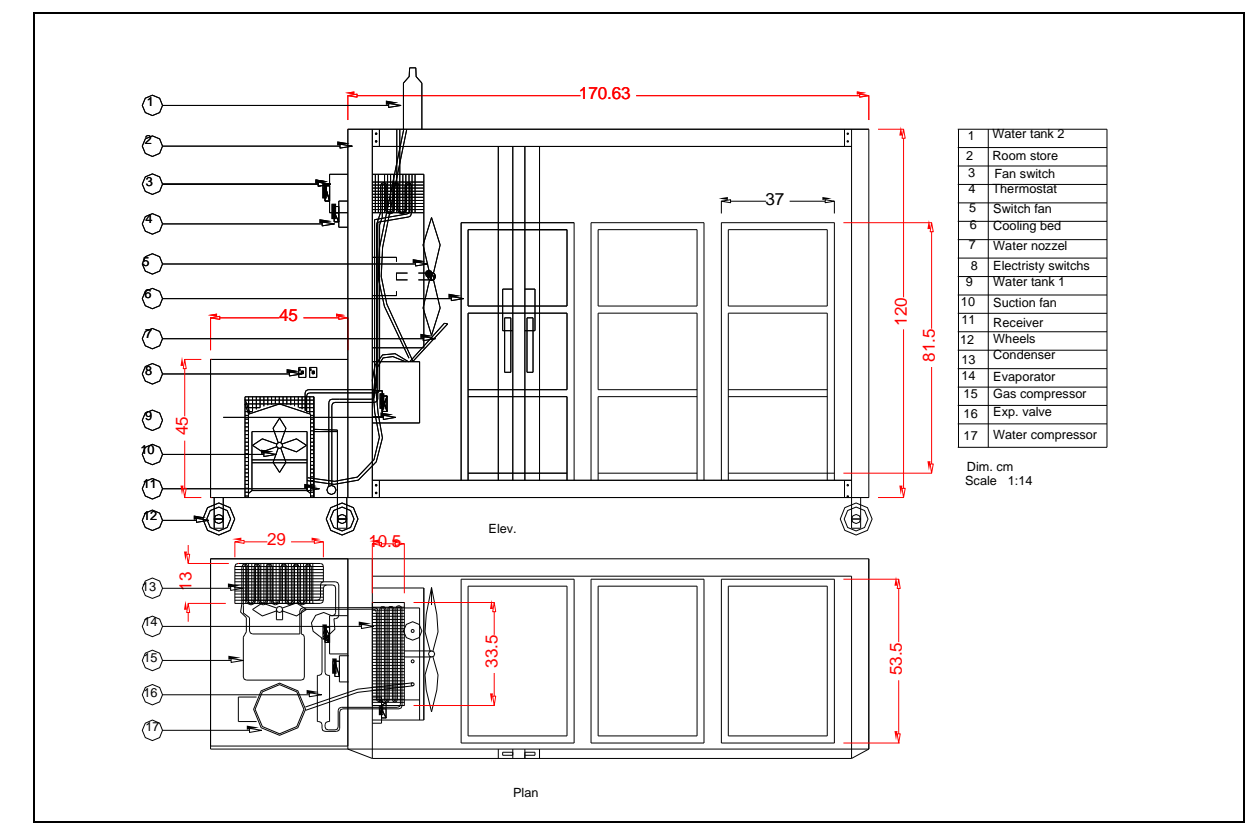

Fig. (1): Schematic diagram of the portable pre-cooling unite.

A rubber seal was fixed on the edges of the cooling chamber door to prevent leakage of cold air. The cooling unit evaporator, thermostat, humidistat, water tank and air forced fan were installed on the unit frame in a separate accommodation part and a separate door. A humidifying unit shown in Fig. (2) was used to increase the air relative humidity inside the cooling chamber by misting water inside the chamber under controlled condition.

The cooling bed consists of three stands made of steel angle $(3 \times 3 \mathrm{~cm})$ installed inside the cooling chamber. Each stand was divided into three parts to accommodate the product packages.

Product package consists of nine boxes with capacity of 5 and $4 \mathrm{~kg}$ for large and medium volume tomato fruits, respectively. The tested packages (rectangular shape boxes) were made of wood with dimensions of $50 \mathrm{~cm}$ long, $33 \mathrm{~cm}$ wide and $10 \mathrm{~cm}$ high. The longer sides of each box (facing the air moving direction) were perforated at vent percentages of 4,6 and $8 \%$. Experimental Treatments:

The laboratory experiments were conducted at three levels of air temperature $\left(4,7\right.$ and $\left.10^{\circ} \mathrm{C}\right)$, three levels of air velocity $(3.7,4.8$ and $5.4 \mathrm{~m} / \mathrm{s})$, three levels of packages vents percentage (4, 6 and $8 \%$ ) and two volumes of tomato fruits (medium and large). 
Abd-Alla, H.E. et al.

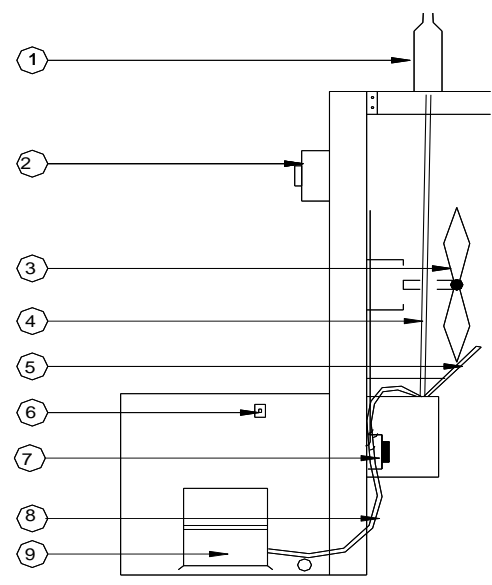

\begin{tabular}{|r|c|}
\hline 1 & Water tank $_{2}$ \\
\hline 2 & Fan switch \\
\hline 3 & Forced fan \\
\hline 4 & Water tube \\
\hline 5 & Water nozzle \\
\hline 6 & Elec. switch \\
\hline 7 & Humidistat \\
\hline 8 & Air tube \\
\hline 9 & Air compressor \\
\hline
\end{tabular}

Fig. (2): Schematic diagram of the humidifying unit

\section{Estimating Half and Seven-Eighth Cooling Times:}

As shown in Fig. (3) regression analyses were carried out on the dimensionless temperature data in the exponential form (temperature ratio) to determine the half and seven-eighth cooling times using the following equation.

$$
\theta=J \exp (-C t)
$$

From the regression analyses the lag factors $(\mathrm{J})$ and the cooling coefficient $(\mathrm{C})$ were determined and hence, the half $(\mathrm{H})$ and seven-eighth $(\mathrm{S})$ cooling times were calculated by means of the following equations.

$$
\begin{aligned}
& H=\frac{\ln 2 J}{C} \\
& S=\frac{\ln 8 J}{C}
\end{aligned}
$$



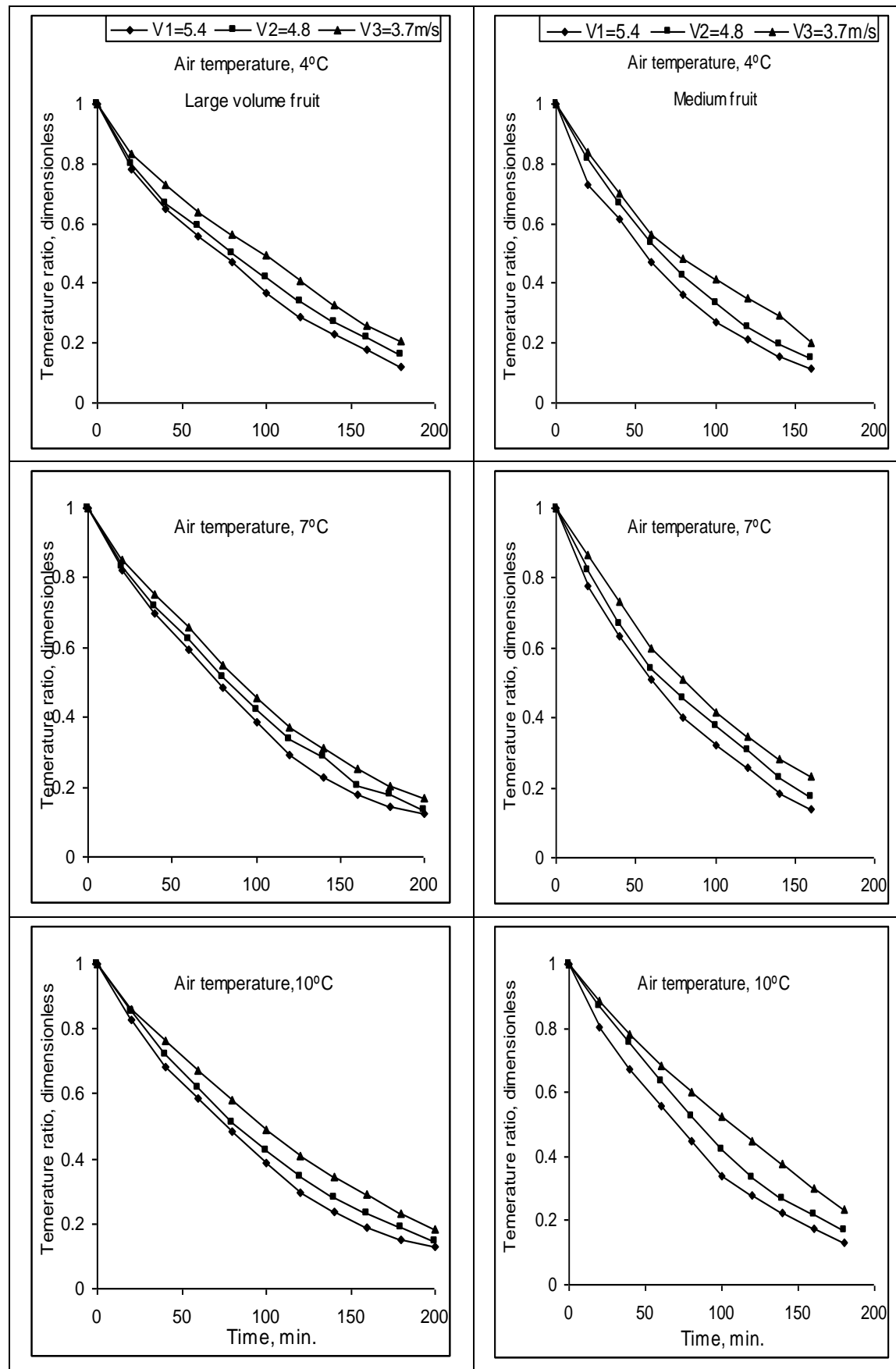

Fig. (3): Average temperature ratio of tomato fruits as related to cooling time for different air cooling temperature and air velocity at packages vents percentage of $4 \%$. 
Abd-Alla, H.E. et al.

\section{Experimental Measurements and Test Procedure:}

During the course of experimental work, several measurements were conducted either directly or indirectly depending on the natural of the measurement itself. The measurements included fruit core temperature, cooling air temperature, air velocity, relative humidity, product weight loss, fruit firmness, and fruit decay.

Freshly harvested tomato var. (super strain B) at ripening stage (red color) were collected from private farm in El-Ruid area - Kafr El-Sheikh Governorate

Prior to each experimental run, the fruits sample was sorted to select the sound fruits with similar volume. The selected fruits of similar volumes were loaded inside the package and left inside the laboratory to attain the ambient temperature.

The temperature of the air cooler was adjusted to the required level using a precious thermostat. This was checked using the universal measuring system model (KAYE, DIG-4) with a set of thermocouples (Type-T) suspended at front of the fan and at different locations of the cooling chamber. Further more the desired air velocity was adjusted using the air velocity control switch and the air velocity meter model J.M-32. The relative humidity was adjusted at $85 \pm 2$ using the humidifying unit and the digital air relative humidity meter model H.K-21 to avoid water losses from the product, according to Alexandria Post Harvest Center (APHC), cited by Desuki et al., (2001).

The packing method of each package was done considering the possible similarity of fruit volume and weight. The large fruit volume weight of tomato packages was about $5 \pm 0.25 \mathrm{~kg}$, while package weight of the medium fruit volume was $4 \pm 0.25 \mathrm{~kg}$. Eighteen thermocouples of the universal measuring system (Type-T) were used to measure product temperature. Two thermocouples were inserted at the center of two randomly selected fruits of each package. The average temperature of each group were taken and the experiment stopped when the average temperature of the three group was decreased to approximately $12.5 \%$ of the difference between the initial temperature of the fruits and the temperature of the cooling air (seven-eighth cooling time).

Two different sets of pre-cooled and none pre-cooled samples of tomatoes were stored at $10^{\circ} \mathrm{C}$ and $85 \% \mathrm{RH}$ for tomato (Desuki et al., 2001) to avoid chilling injury. Two similar sets were also stored at room temperature of $27{ }^{\circ} \mathrm{C}( \pm 3)$ and $59 \%( \pm 2) \mathrm{RH}$ as control. Sample of each treatment were taken every two days for the cooled storage treatment and every one day for the ambient storage treatment to measure quality changes during three storage process. Quality evaluations tests of samples included fruit firmness using the fruit firmness meter Effige with $8 \mathrm{~mm}$ penetration prope, weight losses and a visual fruit decay) were conducted. 


\section{RESULTS AND DISCUSSION}

\section{Temperature Change Of The Fruits:}

Figures (4) and (5) illustrate the change of core temperature as related to cooling time of tomato fruits pre-cooled at different level of air velocity, air temperature, percentage of packages vents and volume of fruits (large and medium). In general, rapid drop in product temperature was observed at the beginning of cooling process and the cooling rate starts to decline as the product temperature approaches the final required temperature. The figures show that the temperature of the fruits at the end position of the cooling chamber was always higher than that of the middle and front as well.

The Cooling Coefficient $(\mathrm{C})$ and Lag Factor $(\mathrm{J})$ :

Table (1) illustrates the value of the coefficient of determination $\left(R^{2}\right)$, lag factor (J), cooling coefficient (C) and standard error (S.E) for tomato fruits. As can be seen from table (1) the coefficient of determination $\left(R^{2}\right)$ ranged from 0.9418 to 0.9992 and the standard error ranged from 2.21 to 19.82 . Mean while, the lag factor $(\mathrm{J})$ ranged from 0.9258 to 1.2148 .

As can also be seen from table (1) and figure (6) the values of cooling coefficient $(C)$ increased with the increase of air velocity $(V)$, increase of packages vents percentage, decrease of fruit volume and decrease of cooling air temperature.

Table (1): The lag factor ( $\mathrm{J}$ ) and cooling coefficient (C) of tomato fruits cooled under different experimental variables.

\begin{tabular}{|c|c|c|c|c|c|c|c|c|c|c|c|c|c|c|}
\hline \multirow{3}{*}{ 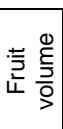 } & \multirow{3}{*}{ 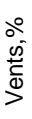 } & \multirow{3}{*}{$\begin{array}{l}0 \\
\stackrel{\circ}{E} \\
\stackrel{\dot{O}}{0} \\
\stackrel{0}{-}\end{array}$} & \multicolumn{12}{|c|}{ Air velocity, $\mathrm{m} / \mathrm{s}$} \\
\hline & & & \multicolumn{4}{|c|}{5.4} & \multicolumn{4}{|c|}{4.8} & \multicolumn{4}{|c|}{3.7} \\
\hline & & & $\mathrm{J}$ & $\begin{array}{c}\mathrm{C}, \\
\text { min. }^{-1}\end{array}$ & $\mathrm{R}^{2}$ & S.E & $\mathrm{J}$ & $\begin{array}{c}\mathrm{C}, \\
\text { min. }^{-1}\end{array}$ & $\mathrm{R}^{2}$ & S.E & $\mathrm{J}$ & $\begin{array}{c}\mathrm{C}, \\
\text { min. }^{-1}\end{array}$ & $\mathrm{R}^{2}$ & S.E \\
\hline \multirow{9}{*}{$\begin{array}{l}\text { ठ্ড } \\
\text { ప్త }\end{array}$} & \multirow{3}{*}{8} & 4 & 0.9855 & 0.0177 & 0.9947 & 6.12 & 0.9701 & 0.0161 & 0.9949 & 6.1 & 1.055 & 0.0145 & 0.9983 & 3.48 \\
\hline & & 7 & 1.0273 & 0.0171 & 0.9985 & 3.53 & 1.0891 & 0.0155 & 0.9926 & 9.13 & 1.0784 & 0.0126 & 0.9851 & 9.92 \\
\hline & & 10 & 1.0145 & 0.0146 & 0.995 & 5.49 & 1.0089 & 0.0137 & 0.9989 & 2.6 & 1.0568 & 0.0123 & 0.997 & 4.33 \\
\hline & \multirow{3}{*}{6} & 4 & 1.0318 & 0.0135 & 0.9968 & 4.51 & 1.028 & 0.0128 & 0.9971 & 4.03 & 1.0794 & 0.0116 & 0.9905 & 7.31 \\
\hline & & 7 & 1.1421 & 0.0132 & 0.982 & 10.4 & 1.1637 & 0.0124 & 0.9418 & 19.82 & 1.0887 & 0.0095 & 0.9838 & 7.82 \\
\hline & & 10 & 1.1199 & 0.0123 & 0.9774 & 10.9 & 1.1291 & 0.0112 & 0.9778 & 10.85 & 1.1136 & 0.0093 & 0.9744 & 10.51 \\
\hline & \multirow{3}{*}{4} & 4 & 1.0487 & 0.0112 & 0.9881 & 7.90 & 1.0561 & 0.0102 & 0.9852 & 8.76 & 1.1002 & 0.0093 & 0.9804 & 9.93 \\
\hline & & 7 & 1.0723 & 0.0109 & 0.9947 & 5.57 & 1.0776 & 0.01 & 0.9906 & 6.8 & 1.0863 & 0.0092 & 0.9938 & 5.51 \\
\hline & & 10 & 1.0493 & 0.0105 & 0.9968 & 4.18 & 1.0723 & 0.0098 & 0.9961 & 4.64 & 1.1023 & 0.0088 & 0.9861 & 7.88 \\
\hline \multicolumn{3}{|c|}{ Mean } & 1.0546 & 0.0134 & 0.9916 & 6.25 & 1.0731 & 0.0124 & 0.9891 & 6.81 & 1.0851 & 0.0108 & 0.9864 & 7.6456 \\
\hline \multirow{9}{*}{$\begin{array}{l}\frac{\dot{E}}{5} \\
\frac{\bar{g}}{0} \\
\sum\end{array}$} & \multirow{3}{*}{8} & 4 & 0.9924 & 0.0199 & 0.9983 & 3.87 & 1.0167 & 0.0187 & 0.9978 & 4.12 & 0.9997 & 0.0154 & 0.9979 & 3.77 \\
\hline & & 7 & 0.9258 & 0.0179 & 0.9890 & 8.94 & 0.9278 & 0.0167 & 0.9968 & 5.04 & 0.9964 & 0.0150 & 0.9992 & 2.21 \\
\hline & & 10 & 0.9841 & 0.0175 & 0.9861 & 9.84 & 0.9335 & 0.0165 & 0.9965 & 5.15 & 0.9942 & 0.0145 & 0.9894 & 8.78 \\
\hline & \multirow{3}{*}{6} & 4. & 1.0084 & 0.1530 & 0.9972 & 4.3 & 1.0443 & 0.0146 & 0.9981 & 3.74 & 1.0894 & 0.0130 & 0.9854 & 10.18 \\
\hline & & 7 & 1.1138 & 0.0151 & 0.9894 & 8.28 & 1.1404 & 0.0141 & 0.9821 & 11.15 & 1.0976 & 0.0109 & 0.9755 & 11.07 \\
\hline & & 10 & 1.1006 & 0.0149 & 0.9847 & 9.80 & 1.1411 & 0.0134 & 0.9775 & 11.86 & 1.0941 & 0.0106 & 0.9817 & 9.24 \\
\hline & \multirow{3}{*}{4} & 4 & 1.0170 & 0.0133 & 0.9970 & 4.25 & 1.0662 & 0.0121 & 0.9970 & 4.25 & 1.053 & 0.0100 & 0.9899 & 7.05 \\
\hline & & 7 & 1.0266 & 0.0121 & 0.9956 & 4.68 & 1.0566 & 0.0111 & 0.9909 & 6.82 & 1.0678 & 0.0097 & 0.9958 & 4.39 \\
\hline & & 10 & 1.0463 & 0.0112 & 0.9968 & 4.09 & 1.1198 & 0.0104 & 0.9910 & 6.93 & 1.1696 & 0.0092 & 0.9592 & 14.4 \\
\hline \multicolumn{3}{|c|}{ ean } & 1.0240 & 0.0305 & 0.9939 & 5.86 & 1.0546 & 0.0142 & 0.9914 & 6.812 & 1.0603 & 0.0120 & 0.9862 & 7.80 \\
\hline
\end{tabular}


Abd-Alla, H.E. et al.
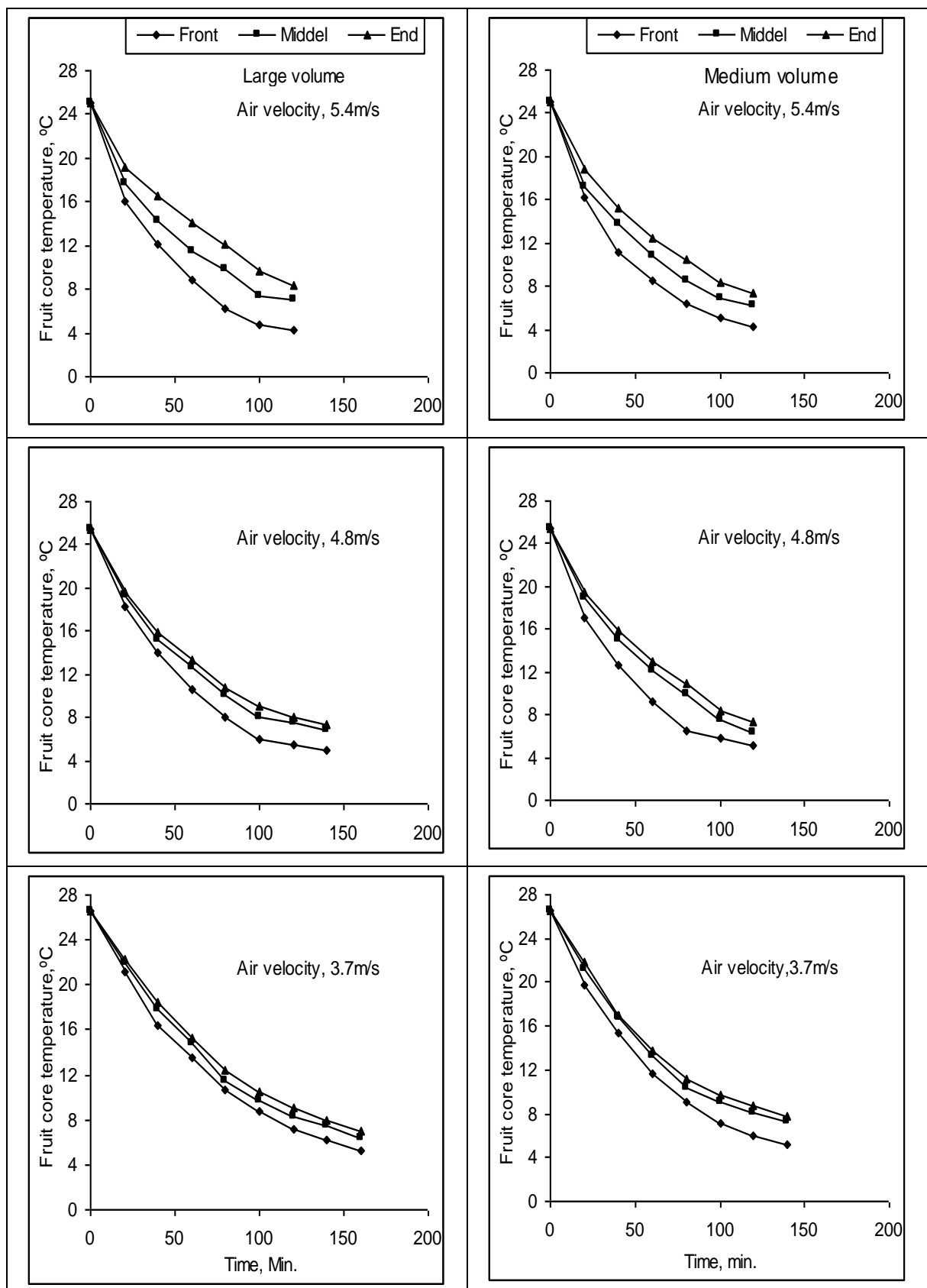

Fig. (4): Average core of tomato fruits temperature as related to cooling time for the minimum air cooling temperature of $4^{\circ} \mathrm{C}$ and packages vents percentage of $8 \%$. 


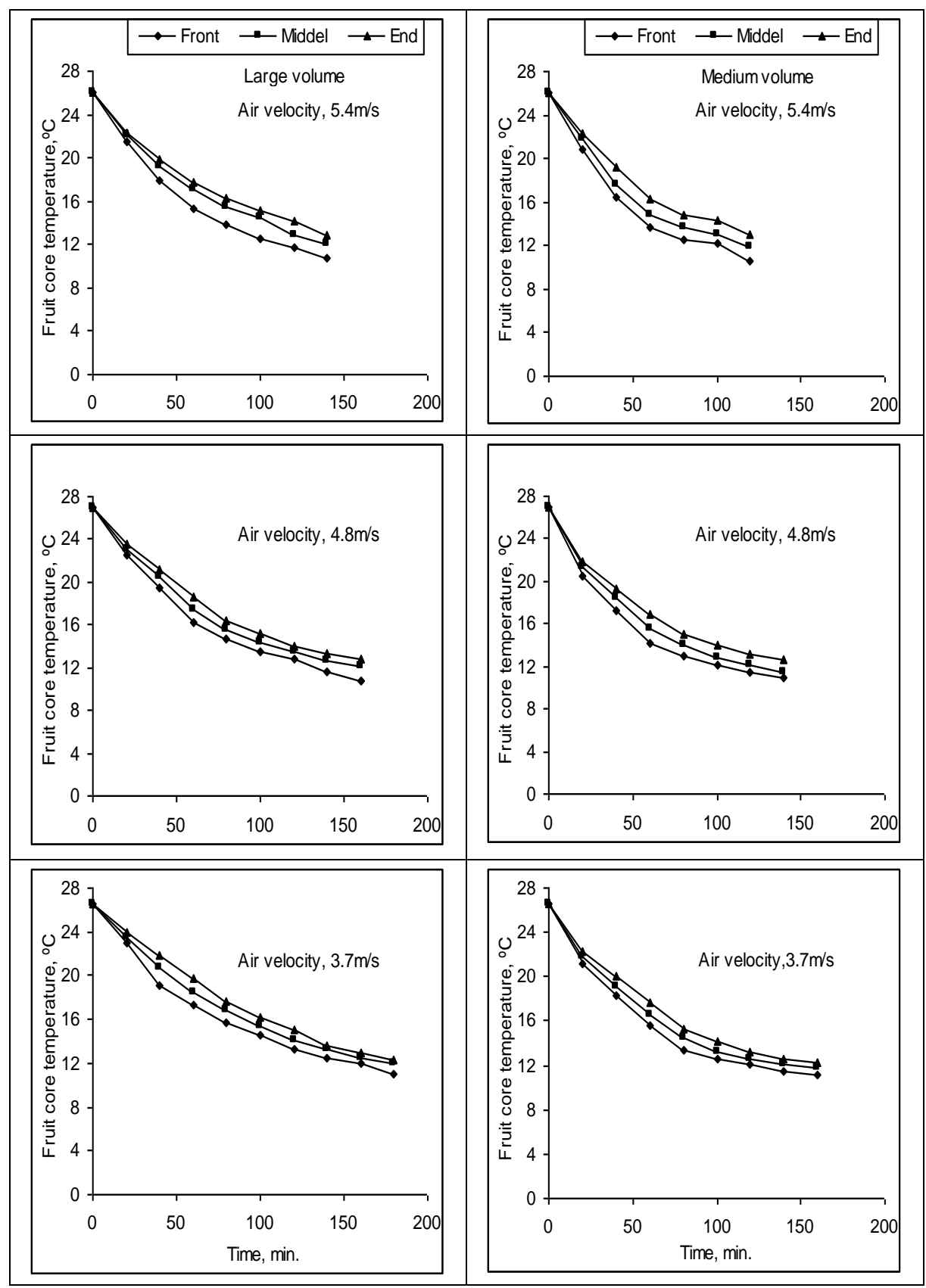

Fig. (5): Average core temperature of tomato fruits as related to cooling time for maximum air cooling temperature of $10^{\circ} \mathrm{C}$ and packages vents percentage of $8 \%$. 
Abd-Alla, H.E. et al.
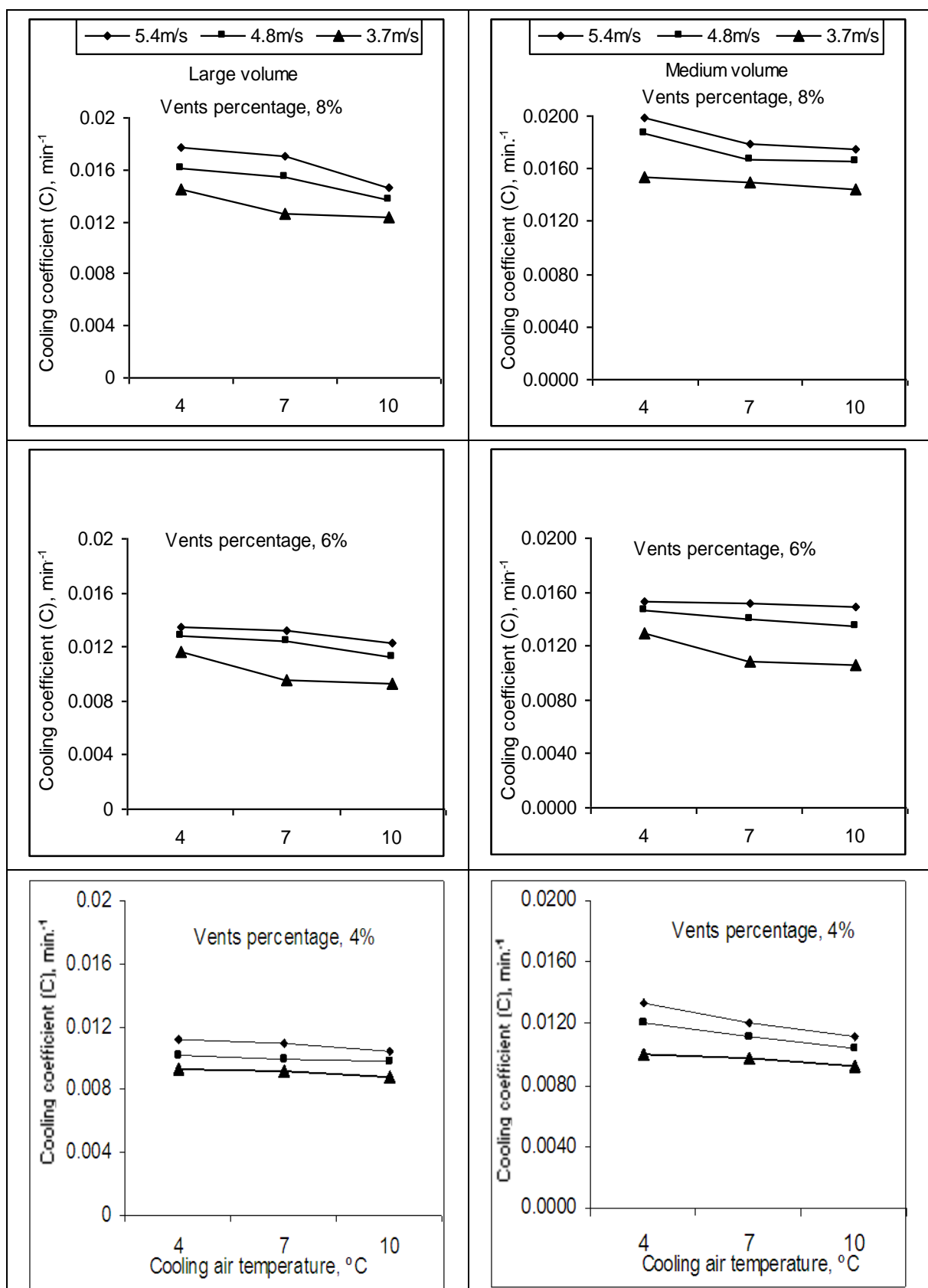

Fig. (6): Effect of cooling air temperature on cooling coefficient (C) at different levels of air velocity, packages vents percentage and volume for tomato fruit 
Half and Seven-eighth Cooling Times:

As can be seen in table (2), the cooling rate of tomato fruits increased with the increase of air velocity and the packages vents percentage, while it was decreased with the increase of cooling temperature and increase of product volume. For large volume tomato fruits and packages vents of $8 \%$, decreasing the cooling air temperature from 10 to $4^{\circ} \mathrm{C}$ decreased the seven-eighth cooling times from 173.6 to $147.1,152.4$ to 127.3 and 143.4 to $116.7 \mathrm{~min}$. for air velocity of $3.7,4.8$ and $5.4 \mathrm{~m} / \mathrm{s}$, respectively. The corresponding results for the medium volume fruit were 143.0 to 135 , 121.9 to 112.1 and 118 to 104.1 min, respectively. Mean while, half cooling time decreased from 60.8 to $51.5,51.2$ to 41.2 and 48.5 to $38.3 \mathrm{~min}$. for large volume fruits and from 47.4 to $45,37.8$ to 38.0 and 37.8 to $34.4 \mathrm{~min}$. for medium volume fruit. Package vents percentage of 6 and $4 \%$ showed similar trend.

Table (2): Average values of half and seven-eighth cooling times of tomato packages located at front, middle and end different of stands levels.

\begin{tabular}{|c|c|c|c|c|c|c|c|c|}
\hline \multirow{3}{*}{ Volume } & \multirow{3}{*}{$\begin{array}{c}\text { Pack. } \\
\text { vents,\% }\end{array}$} & \multirow{3}{*}{$\underset{{ }^{\circ} \mathrm{C}}{\text { Temp., }}$} & \multicolumn{6}{|c|}{ Air velocity, m/s } \\
\hline & & & \multicolumn{2}{|c|}{5.4} & \multicolumn{2}{|c|}{4.8} & \multicolumn{2}{|c|}{3.7} \\
\hline & & & $\mathrm{H}$, min. & $\mathrm{S}, \mathrm{min}$. & $\mathrm{H}$, min. & S, min. & $\mathrm{H}$, min. & $\mathrm{S}, \mathrm{min}$. \\
\hline \multirow{9}{*}{ ब } & \multirow{3}{*}{8} & 4 & 38.3 & 116.7 & 41.2 & 127.3 & 51.5 & 147.1 \\
\hline & & 7 & 42.1 & 123.2 & 50.2 & 139.7 & 61 & 171 \\
\hline & & 10 & 48.5 & 143.4 & 51.2 & 152.4 & 60.8 & 173.6 \\
\hline & \multirow{3}{*}{6} & 4 & 53.7 & 156.4 & 56.3 & 164.6 & 66.3 & 185.8 \\
\hline & & 7 & 62.6 & 167.6 & 68.13 & 179.9 & 81.9 & 227.8 \\
\hline & & 10 & 65.6 & 178.3 & 72.7 & 196.5 & 86.1 & 235 \\
\hline & \multirow{3}{*}{4} & 4 & 66.1 & 189.9 & 73.3 & 209.2 & 84.8 & 233.9 \\
\hline & & 7 & 70.0 & 197.2 & 76.8 & 215 & 84.3 & 235 \\
\hline & & 10 & 70.6 & 202.6 & 77.9 & 219.3 & 89.8 & 247.4 \\
\hline \multirow{9}{*}{ 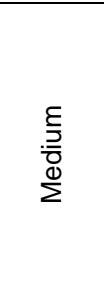 } & \multirow{3}{*}{8} & 4 & 34.4 & 104.1 & 38.0 & 112.1 & 45.0 & 135 \\
\hline & & 7 & 34.4 & 111.9 & 37.0 & 120.0 & 46.0 & 138.4 \\
\hline & & 10 & 37.8 & 118 & 37.8 & 121.9 & 47.4 & 143.0 \\
\hline & \multirow{3}{*}{6} & 4 & 45.9 & 136 & 50.4 & 145.4 & 59.9 & 166.5 \\
\hline & & 7 & 53.0 & 144.8 & 58.5 & 157 & 72.1 & 199.3 \\
\hline & & 10 & 53.0 & 146.0 & 61.6 & 165.0 & 73.9 & 204.7 \\
\hline & \multirow{3}{*}{4} & 4 & 53.4 & 157.6 & 62.6 & 177.2 & 74.5 & 213 \\
\hline & & 7 & 59.5 & 174.0 & 67.4 & 192.3 & 78.2 & 221.1 \\
\hline & & 10 & 65.9 & 189.7 & 77.5 & 210.8 & 92.4 & 243.1 \\
\hline
\end{tabular}

\section{Quality Evaluation Tests During Storage Process}

Quality evaluation tests included measurements of fruit weight loss, fruit defects and fruit firmness were conducted every two days for the cold storage treatment and every one day for the room storage method. The obtained results could be presented as follows:

\section{Weight Losses of Tomato}

As shown in tables ( 3 and 4 ) there is a considerable increase in weight losses of tomato fruits at both cooled and room storage methods. When the cooled storage period elongated to 14 days, the weight losses of the pre-cooled fruits increased from 0 to $5.7 \%$ and from 0 to $5.3 \%$ for large 
Abd-Alla, H.E. et al.

and medium volume pre-cooled samples, respectively. While the corresponding values for the none pre-cooled samples ranged from 0 to $7.6 \%$ and from 0 to $7.1 \%$ for large and medium volume fruits, respectively. On the other hand, similar weight losses were observed as the room storage period elongated to 4 days only. The above mentioned observations revealed that during the early stage of cooled storage, the lower rate of water transpiration and respiration activity, resulting in lower loss in water and organic compounds which slightly decrease the rate of fruit weight losses.

\section{Fruit defects}

The defects like discoloration, pitting and softening appeared after 12 days of cooled storage for the pre-cooled and none pre-cooled samples, respectively. While the defects appeared after 7 and 5 days only for the precooled and none pre-cooled in room storage as shown in tables ( 3 and 4). In general it was clear that the defects increased at the none pre-cooled sample as compared to the pre-cooled samples stored under both cooled and room storage methods. The increasing in water loss in room storage damaged the flesh structure and the cell membrane resulting in more pathological and physiological changes leading to the increased rate of various fungi invasion as mentioned by (Thumula, 2006).

\section{Fruit firmness}

The firmness of tomato fruits gradually decreased with increasing the storage time in both cooled and room storage methods. As shown in tables ( 3 and 4) when the cooled storage period was elongated to 14 days, the precooled fruit firmness decreased from 6.9 to $4 \mathrm{~kg} / \mathrm{cm}^{2}$ and from 7.4 to 4.2 $\mathrm{kg} / \mathrm{cm}^{2}$ for large and medium volume fruit, respectively sample. While the corresponding value for the none pre-cooled sample was from 6.9 to 2.9 $\mathrm{kg} / \mathrm{cm}^{2}$ and from 7.4 to $3.2 \mathrm{~kg} / \mathrm{cm}^{2}$ for large and medium volume fruits, respectively.

Table (3): Effect of pre-cooling treatment of tomato fruits on fruit weight losses (WL, \%), defects (\%), and firmness $\left(\mathrm{Kg} / \mathrm{cm}^{2}\right)$ during cold storage method.

\begin{tabular}{|c|c|c|c|c|c|c|c|c|c|c|}
\hline \multirow{2}{*}{$\begin{array}{c}\text { Quality } \\
\text { parameters }\end{array}$} & \multirow{2}{*}{ Treatments } & \multirow{2}{*}{$\begin{array}{c}\text { Fruit } \\
\text { volumes }\end{array}$} & \multicolumn{8}{|c|}{ Storage period, day } \\
\hline & & & 0 & 2 & 4 & 6 & 8 & 10 & 12 & 14 \\
\hline \multirow{4}{*}{$\begin{array}{c}\text { Weight } \\
\text { losses, \% }\end{array}$} & \multirow{2}{*}{ Pre-cooled } & Large & 0 & 0.3 & 0.7 & 1.2 & 1.9 & 3.3 & 4.2 & 5.7 \\
\hline & & Medium & 0 & 0.25 & 0.6 & 1.0 & 1.7 & 2.5 & 3.6 & 5.3 \\
\hline & \multirow{2}{*}{$\begin{array}{l}\text { None pre- } \\
\text { cooled }\end{array}$} & Large & 0 & 1.1 & 1.3 & 2.5 & 3.6 & 4.7 & 5.7 & 7.6 \\
\hline & & Medium & 0 & 0.9 & 1.2 & 2.2 & 3.2 & 4.2 & 5.2 & 7.1 \\
\hline \multirow{4}{*}{ Defects,\% } & \multirow{2}{*}{ Pre-cooled } & Large & - & - & - & - & - & - & 4.1 & 5.4 \\
\hline & & Medium & - & - & - & - & - & - & 1.4 & 3.3 \\
\hline & \multirow{2}{*}{$\begin{array}{l}\text { None pre- } \\
\text { cooled. }\end{array}$} & Large & - & - & - & - & - & - & 7.3 & 15.6 \\
\hline & & Medium & - & - & - & - & - & - & 5.8 & 11.7 \\
\hline \multirow{4}{*}{$\begin{array}{l}\text { Firmness, } \\
\text { kg/cm }\end{array}$} & \multirow{2}{*}{ Pre-cooled } & Large & 6.9 & 5.9 & 5.7 & 5.6 & 5.3 & 4.8 & 4.4 & 4 \\
\hline & & Medium & 7.4 & 6.2 & 6.1 & 6 & 5.7 & 4.9 & 4.6 & 4.2 \\
\hline & \multirow{2}{*}{$\begin{array}{l}\text { None pre- } \\
\text { cooled }\end{array}$} & Large & 6.9 & 5.6 & 5.5 & 4.6 & 4.3 & 3.8 & 3.3 & 2.9 \\
\hline & & Medium & 7.4 & 5.7 & 5.5 & 4.9 & 4.4 & 3.9 & 3.6 & 3.2 \\
\hline
\end{tabular}


Table (4): Effect of pre-cooling treatment of tomato fruits on fruit weight losses (WL, \%), defects (\%) and firmness $\left(\mathrm{Kg} / \mathrm{cm}^{2}\right)$ during room storage methods.

\begin{tabular}{|c|c|c|c|c|c|c|c|c|c|c|c|c|c|}
\hline \multirow{2}{*}{$\begin{array}{c}\text { Quality } \\
\text { parameters }\end{array}$} & \multirow{2}{*}{ Treat. } & \multirow{2}{*}{ Fruit vol. } & \multicolumn{11}{|c|}{ Storage period, day } \\
\hline & & & 0 & 1 & 2 & 3 & 4 & 5 & 6 & 7 & 8 & 9 & 10 \\
\hline \multirow{4}{*}{$\begin{array}{l}\text { Weight } \\
\text { losses, \% }\end{array}$} & \multirow{2}{*}{$\begin{array}{c}\text { Pre- } \\
\text { cooled }\end{array}$} & Large & 0 & 2.3 & 3.7 & 4.9 & 5.9 & 7.4 & 8.6 & 9.4 & 10.2 & 11 & 11.9 \\
\hline & & Medium & 0 & 2.1 & 3.5 & 4.6 & 5.6 & 7 & 8.1 & 9 & 9.8 & 10.6 & 11.4 \\
\hline & \multirow{2}{*}{\begin{tabular}{|c|}
$\begin{array}{c}\text { None pre- } \\
\text { cooled }\end{array}$ \\
\end{tabular}} & Large & 0 & 3.5 & 4.9 & 6.1 & 7.6 & 8.7 & 9.9 & 10.8 & 11.6 & 12.4 & 13.2 \\
\hline & & Medium & 0 & 3.2 & 4.6 & 5.7 & 7.1 & 7.3 & 8.4 & 9.4 & 10.2 & 11 & 12 \\
\hline \multirow{4}{*}{ Defects, \% } & \multirow{2}{*}{$\begin{array}{c}\text { Pre- } \\
\text { cooled } \\
\end{array}$} & Large & - & - & - & - & - & - & - & 6.4 & 12.6 & 15.7 & 25.8 \\
\hline & & Medium & - & - & - & - & - & - & - & 4.2 & 9.4 & 14.7 & 20.9 \\
\hline & \multirow{2}{*}{$\begin{array}{c}\text { None pre- } \\
\text { cooled }\end{array}$} & Large & - & - & - & - & - & 2.4 & 5.4 & 12.5 & 18.8 & 35.9 & 50.3 \\
\hline & & Medium & - & - & - & - & - & 2.2 & 3.5 & 7.8 & 15.5 & 25.4 & 35.3 \\
\hline \multirow{4}{*}{$\begin{array}{c}\text { Firmness, } \\
\mathrm{kg} / \mathrm{cm} 2\end{array}$} & \multirow{2}{*}{$\begin{array}{c}\text { Pre- } \\
\text { cooled } \\
\end{array}$} & Large & 6.9 & 5.8 & 5.3 & 4.8 & 4.3 & 3.9 & 3.4 & 2.6 & 2.3 & 2 & 1.8 \\
\hline & & Medium & 7.4 & 6.1 & 5.7 & 5.3 & 4.8 & 4.4 & 3.9 & 3.5 & 2.9 & 2.5 & 2.2 \\
\hline & \multirow{2}{*}{$\begin{array}{c}\text { None pre- } \\
\text { cooled }\end{array}$} & Large & 6.9 & 5.2 & 4.5 & 3.9 & 3.4 & 2.9 & 2.5 & 2.3 & 1.7 & 1.5 & 1.2 \\
\hline & & Medium & 7.4 & 5.8 & 4.9 & 4.5 & 4.1 & 3.4 & 3.2 & 2.5 & 2.1 & 1.7 & 1.4 \\
\hline
\end{tabular}

On the other hand for the pre-cooled samples when the room storage period was elongated to 10 days the fruit firmness decreased from 6.9 to 1.8 $\mathrm{kg} / \mathrm{cm}^{2}$ and from 7.4 to $2.2 \mathrm{~kg} / \mathrm{cm}^{2}$ for large and medium fruit volumes, respectively. The corresponding values for the none pre-cooled samples ranged from 6.9 to $1.2 \mathrm{~kg} / \mathrm{cm}^{2}$ and from 7.4 to $1.4 \mathrm{~kg} / \mathrm{cm}^{2}$ for large and medium fruit volumes, respectively. Increasing the fruit firmness for the cooled storage condition compared to the room storage could be attributed to the reduction of respiration rate and the decrease in water loss which resulted in retention of firmness.

\section{CONCLUSIONS}

1- The temperature of the fruits at the end position of the cooling chamber was always higher than that of the middle and fronts as well.

2- The values of cooling coefficient (C) increased with the increase of air velocity (V), increase of packages vents percentage, decrease of fruit volume and decrease of cooling air temperature.

3- The seven-eighth and half cooling times of tomato fruits decreased with the increase of air velocity and increase of packages vents percentage while, they were increased with the increase of cooling temperature and increase of product volume.

4- The lower rate of water transpiration and respiration activity of the precooled product, resulting in lower loss in water, lower percentage of defect, and higher fruit firmness. 


\section{REFERENCES}

Abd-Alla, H.El. (1997). A small unit for fruits and vegetables hydro-cooling $5^{\text {th }}$ conference of Misr Society. Agr. Eng. $9^{\text {th }}$ sept 1997: 181-191.

Brosnan, T. and S., Da-Wen (2001). Pre-cooling techniques and applications for horticultural products- a review. International Journal of Refrigeration 24; 154-170.

Dincer, I.; M., Yildiz; M., Loker and H., Gun (1992). Process parameters for hydro-cooling apricots, plums and peaches. Int.J. Food Sci. Technol., $27,347-352$.

Farragher, J.D.; A., Borochov; V., Keren-Paz; Z., Adam and A.H.,Helvey (1984). Changes in parameters of cell senescence in carnation flowers after cold storage. Scientia Hort, 22:295-302.

Ferreira, M.D.; J.K., Brecht; S.A., Sargent and J.J., Aracena (1994). Physiological responses of strawberry to film wrapping and precooling methods. Proc. Fla. State Hort. Soc. 107:265-269.

Kader, A.A. (1992). Post harvest Technology of horticultural Crops. University of California, Division of Agriculture and Natural Resources, Publication 3311. 296pp.

Kalbasi-Ashtari, A. (2004). Effect of post harvest pre-cooling process and cyclical heat treatment on the physico-chemical properties of Red Haven peaches and Shahmiveh pears during cold storage. Agricultural engineering international: the CIGR journal of scientific research and development. Manuscript FP 04003. July.

Reina,L.D., H.P., Fleming and E.G., Humphries (1995). Microbial control of cucumber hydro cooling water with Chlorine Dioxide. Journal of Food Protection, 58(5): 541-546.

Schofer, D.P.; J. Anthony; G. Berney and Craig (1992). Portable inexpensive farm built high value crop cooler. American Society of Agricultural Engineers - Paper No. 92-6569, 14 PP.

Shewfelt, R.L. (1986). Post harvest treatment for extending the shelf life of fruits and vegetables. Food Technology, 40 (5):7078 -7089.

Shokr, A.Z.; M.A. Sabbah and A.M., El-Ansary (1994). Forced air prcooling of mangoes in boxes. Misr J. Agric. Eng. 11 (1): 36-51.

Thumula, P. (2006). Studies on storage behaviour of tomato coated with chitosan-Lysozyme films. Published Master D.Thesis, Faculty of Agric. and Environmental sciences, McGill Univ., Montreal, Quebec, Canada.

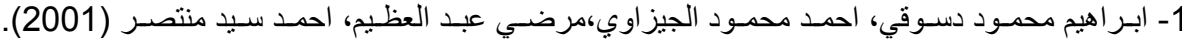

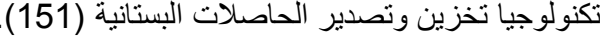
2- وزارة الزر اعة (2008) M.O.A. القطاع الاقتصادي نشرة احصائيات المحاصيل الحقلية. 


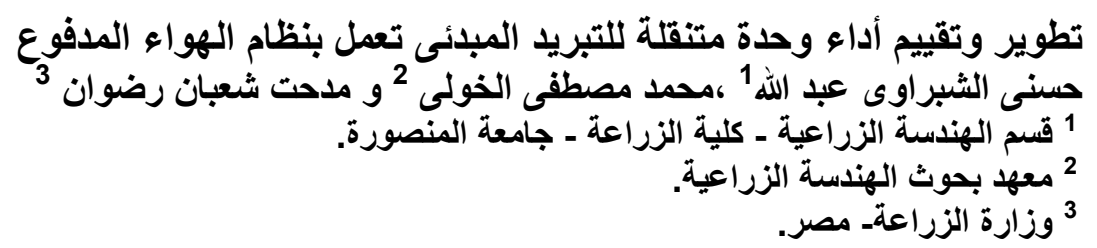

اجريت در اسـة لتطوير وتقييم وحدة متتقلة للتبريد المبدئي للطماطم خلال موسم 20072008 بوحدة بحوث هندسة التصنيع و التداول بمركز ميكنة الارز - ميت التئي الديبة محافظة كفر الثيخ

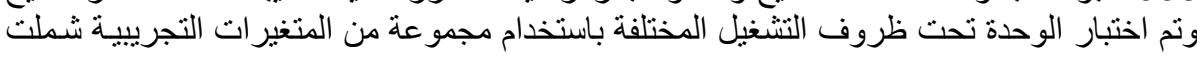

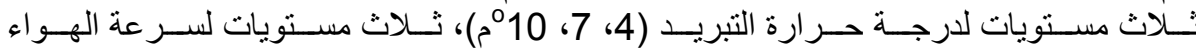

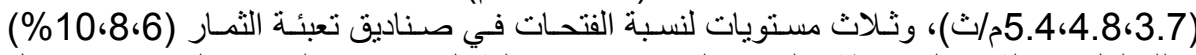

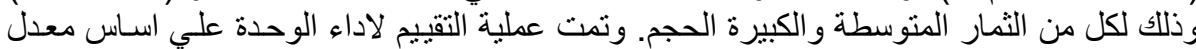

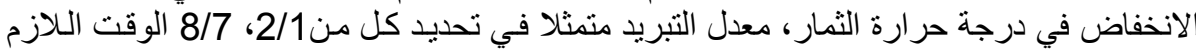

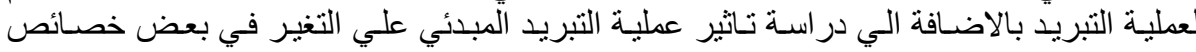

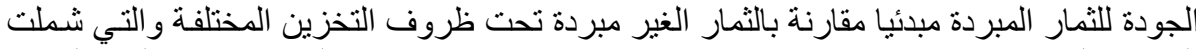

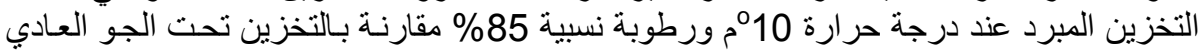

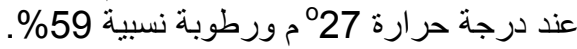

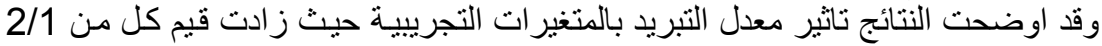

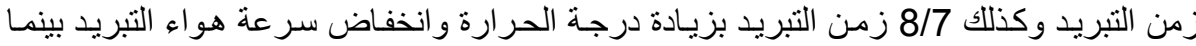

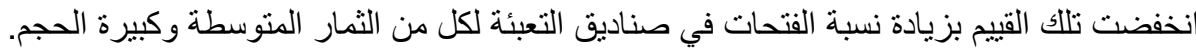

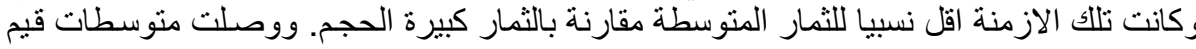

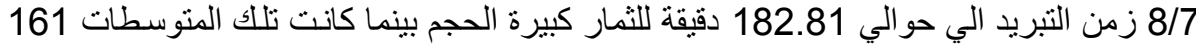

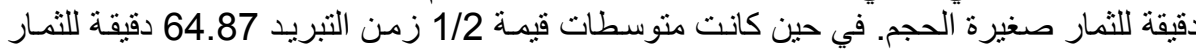

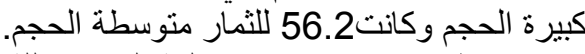

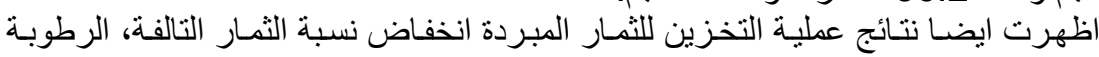

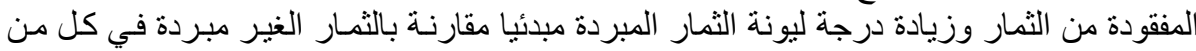
طريقتي التخزين المبرد و التخزين تحت ظرئ لئروف الجو العادي.

كلية الزراعة - جامعة المنصورة كلية الزراعة ـ جامعة قناة السويس المنورة

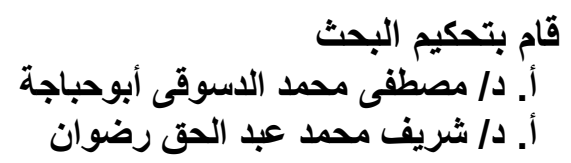

قام بتحكيم البحث مقثم

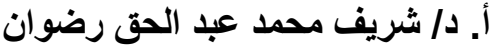

